\title{
Sistem Informasi Akuntansi Manajemen, Pengendalian Manajemen terhadap Kinerja Manajerial dengan Variabel Moderating Teknologi Informasi
}

\author{
Suprantiningrum ${ }^{1 *}$, Aurora Diskayani Lukas ${ }^{2}$ \\ Universitas 17 Agustus 1945 ${ }^{1,2)}$ Semarang \\ hmenteri@gmail.com, auroradiska@gmail.com
}

*Corresponding Author

Submitted: January 9, 2021

Accepted: January 19, 2021

Published: February 3, 2021

\begin{abstract}
The success of garment companies in increasing business competition is influenced by good managerial performance. Managers to achieve optimal performance in planning, control and decision making need the support of management accounting information systems, management control systems and information technology. This study aims to determine the effect of management accounting information systems and management control systems on managerial performance, the effect of management accounting information systems and management control systems on managerial performance with information technology as a moderating variable. The research object is the manager of a garment company in the city of Semarang with a population of 200, sampling using probability sampling, the sample used is 67 managers, determining the number of samples using the Slovin formula. The data used are primary data, data collection using a questionnaire with 5 Likert scale. The data analysis used in this research is validity test, reliability test, multiple linear regression and interaction regression. The results showed that the management accounting information system had a significant positive effect on managerial performance. The management control system has a significant positive effect on managerial performance. Information technology is a moderating variable on the effect of management accounting information systems and management control systems on managerial performance, meaning that information technology strengthens the influence of management accounting information systems and management control systems on managerial performance in garment companies in the city of Semarang.
\end{abstract}

Keywords: Information Technology; Management Accounting Information Systems; Management Control System; Managerial Performance

\section{PENDAHULUAN}

Persaingan bisnis yang semakin meningkat menuntut perusahaan untuk memanfaatkan kemampuan yang ada semaksimal mungkin dan meningkatkan efektifitas dalam pengelolaan manajemen. Salah satu faktor yang mempengaruhi efektifitas pengelolan manajemen yaitu kinerja manajerial pada perusahaan tersebut, kinerja manajerial merupakan kemahiran seorang manajer dalam menjalankan, menyelesaikan tugas dengan berpedoman pada tujuan perusahaan. Kesuksesan yang diraih oleh suatu perusahaan dalam meraih tujuan sangat bergantung kepada kinerja para manajer-manajer, dan sistem 
informasi akuntansi manajemen dapat menjadi alat penghubung, pengendalian, evaluasi dan pelaporan bagi manajer untuk mencapai kinerja manajerial yang baik (Febrianti \& Fitri, 2019).

Tujuan penelitian adalah mengetahui: pengaruh sistem informasi akuntansi manajemen, sistem pengendalian manajemen terhadap Kinerja manajerial pada perusahaan garmen di kota Semarang, dan mengetahui pengaruh interaksi sistem informasi akuntansi manajemen dengan teknologi informasi, pengaruh interaksi sistem pengendalian manajemen dengan teknologi informasi terhadap Kinerja manajerial perusahaan garmen di Kota Semarang

Informasi akuntansi manajemen membantu manajemen mengidentifikasikan suatu masalah, menyelesaikan masalah, dan mengevaluasi kinerja. Informasi akuntansi manajemen dibutuhkan dan digunakan dalam semua lingkup manajemen, meliputi perencanaan, pengendalian dan pengambilan keputusan (Nainggolan, 2015). Informasi merupakan bagian yang berguna bagi perusahaan karena menjadi masukan data pertama dan mendasar dalam setiap tindakan pengambilan keputusan. Sistem Informasi Akuntansi Manajemen (SIAM) adalah pengumpul dan penyimpan data dari semua aktivitas dan transaksi perusahaan, proses data menjadi informasi yang berguna, manajemen data-data, dan kontrol data perusahaan. Sistem informasi akuntansi manajemen yang tidak dijalankan dengan baik oleh manajer perusahaan garmen adalah seringkali di dalam perusahaan seorang manajer melakukan kesalahan yaitu terlambat dalam pengambilan keputusan. Perbedaan penelitian dengan penelitian terdahulu yaitu adanya variable moderating teknologi informasi pada pengaruh sistem informasi akuntansi manajemen dan sistem pengendalian manajemen terhadap kinerja manajerial. Penelitian mengambil obyek perusahaan garmen di semarang dimana masih sedikit penelitian dengan obyek yang sama aka. Penelitian Rumapea et al., (2018), Febrianti \& Fitri, (2019) mengungkapkan Karakteristik sistem informasi akuntansi manajemen berpengaruh positif secara signifikan terhadap kinerja manajerial namun hasil penelitian Irawati \& Ardianshah, (2018) menyatakan karakteristik informasi cakupan dan integrasi yang luas tidak berpengaruh pada kinerja manajerial.

H1 : Sistem informasi akuntansi manajemen berpengaruh positif signifikan terhadap kinerja manajerial perusahaan garmen Kota Semarang.

Seorang manajer selain menggunakan sistem informasi akuntansi manajemen juga harus menerapkan sistem pengendalian manajemen dalam setiap mengambil keputusan. sistem pengendalian manajemen adalah suatu kegiatan yang dilakukan di dalam organisasi secara rutin dan terus menerus. Sistem pengendalian manajemen sangat penting digunakan oleh para manajer tingkat atas untuk menangkap kondisi-kondisi yang tidak kondusif dalam perusahaan dan kegiatan-kegiatan yang tidak efektif dan efisien (Yusuf et al., 2018). Penelitian Tendean et al., (2018) dan Sugianto Yusuf et al., (2018) menemukan

bahwa sistem pengendalian manajemen mempunyai pengaruh positif signifikan terhadap kinerja manajerial.

H2 : Sistem pengendalian manajemen berpengaruh positif signifikan terhadap kinerja manajerial perusahaan garmen Kota Semarang

Kinerja seorang manajer tidak lepas dengan penggunaan teknologi informasi untuk mendapatkan informasi-informasi yang sangat dibutuhkan untuk pengambilan keputusan. Teknologi informasi adalah suatu pemanfaatan teknologi seperti komputer yang digunakan 
untuk mengolah, memproses, mendapatkan, menyusun, menyimpan, memanipulasi data yang menghasilkan informasi yang berkualitas . Teknologi informasi sangat penting bagi manajer untuk membantu menyelesaikan tugas-tugas mereka, sehingga pemanfaatan teknologi informasi dapat mempengaruhi peforma kinerja manajerial (Sutabri, 2014), akan tetapi faktanya masih banyak manajer perusahaan yang tidak menjalankan sistem informasi akuntansi manajemen dengan baik, penerapan sistem pengendalian manajemen yang tidak maksimal dalam perusahaan dan masih rendahnya pengunaan teknologi informasi untuk menunjang kinerja perusahaan. Penelitian Rahmanuari (2017) menemukan bahwa interaksi karakteristik sistem informasi akuntansi manajemen dengan teknologi informasi memperoleh hasil positif signifikan. teknologi informasi memperkuat pengaruh sistem informasi akuntansi manajemen terhadap kinerja manajerial. Penelitian Handayani (Handayani et al., 2020) menghasilkan temuan terdapat pengaruh yang positif dan signifikan antara sistem pengendalian intern pemerintah, pemanfaatan teknologi informasi dan komitmen organisasi terhadap akuntabilitas kinerja instansi pemerintah. Berdasarkan hal tersebut, maka hipotesis dalam penelitian ini adalah:

H3 : Teknologi informasi memperkuat pengaruh sistem informasi akuntansi manajemen terhadap kinerja manajerial perusahaan garmen Kota Semarang

H4 : Teknologi informasi memperkuat pengaruh sistem pengendalian manajemen terhadap kinerja manajerial perusahaan garmen Kota Semarang

\section{STUDI LITERATUR}

Kinerja manajerial adalah penilaian yang dilakukan untuk mengevaluasi hasil kerja seorang manajer dalam menjalankan pekerjaannnya. Kerja keras para manajer dalam menghasilkan kinerja manajerial yang baik akan menghasilkan sebuah keberhasilan untuk mencapai tujuan perusahaan. Informasi akuntansi manajemen, desentralisasi, reward, SDM dan keadaan lingkungan adalah contoh beberapa faktor yang dapat mempengaruhi kinerja manajerial. Perkembangan kinerja manajerial dapat dilihat pada saat setelah melakukan dan menerapkan sistem informasi akuntansi manajemen pada perusahaan. Perkembangan suatu perusahaan untuk mencapai tujuannnya dapat diamati pada kualitas kinerja manajerial di dalam perushaan tersebut (Fuadah et al., 2020) .

Kinerja manajerial adalah kemampuan manajer dalam melaksanakan kegiatan manajerial, antara lain: perencanaan, investigasi, koordinasi, evaluasi, supervisi, pengaturan staf (Missah et al., 2019). Tendean et al., (2018) mengemukakan dimensi pengukuran kinerja manajerial meliputi delapan dimensi kegiatan yaitu : perencanaan, investigasi, Koordinasi, evaluasi, supervisi, staffing, negosiasi, representasi. Kinerja manajerial adalah manajer yang menghasilkan kinerja dengan mengerahkan bakat dan kemampuan, serta usaha beberapa orang lain yang berada di dalam daerah wewenangnya

Sistem informasi akuntansi manajemen adalah suatu sistem yang disediakan dan didesain bagi para manajer untuk mendapatkan informasi (Febrianti \& Fitri, 2019), sedangkan menurut Nainggolan, (2015) Sistem informasi akuntansi manajemen (SIAM) adalah suatu mekanisme pengendalian organisasi, serta merupakan alat yang efektif dalam menyediakan informasi yang bermanfaat guna memprediksi konsekuensi yang mungkin terjadi dari aktivitas yang dilakukan. Tujuan dari sistem informasi akuntansi manajemen adalah menyediakan informasi kepada manajemen yang biasanya digunakan oleh pihak internal perusahaan, seperti manajer eksekutif maupun para pekerja guna menjalankan tugasnya untuk menyusun perencanaan, pengendalian, dan pengambilan keputusan. Manajer membutuhkan informasi yang berfokus pada pesaing, berorientasikan lingkungan eksternal atau pasar dan berjangka panjang, agar dapat menghasilkan 
keputusan yang tepat ditengah persaingan dan perubahan lingkungan bisnis yang tidak pasti (Rumapea et al., 2018) .

Sistem informasi akuntansi manajemen dapat membantu manajer dalam pengendalian aktivitas sehingga diharapkan dapat membantu perusahaan dalam pencapaian tujuan. Febrianti \& Fitri, (2019)mengidentifikasi empat karakteristik sistem informasi akuntansi manajemen yang bermanfaat untuk pengambilan keputusan, yaitu: broad scope (lingkup), timelines (tepat waktu), aggregation (agregasi), dan integration (integrasi). Sistem informasi akuntansi manajemen yang tersedia tersebut akan menjadi efektif apabila sesuai dengan tingkat kebutuhan organisasi.

Sistem pengendalian manajemen merupakan sistem yang mempunyai fungsi sebagai suatu wadah untuk merencanakan target yang akan digapai perusahaan dimasa mendatang. Menyusun aktivitas-aktivitas, mempraktekan serta mengawasi aktivitas dari pelaksanaan yang sudah direncanakan agar tetap pada jalurnya. (Sumarsan, 2013). Tendean et al., (2018) menyatakan sistem pengendalian manajemen adalah suatu kegiatan yang dilakukan di dalam organisasi secara rutin dan terus menerus. Sistem Pengendalian Manajemen dapat menyediakan informasi tentang bagaimana menilai kinerja perusahaan dan manajemen perusahaan serta menyediakan informasi yang akan digunakan sebagai pedoman dalam perencanaan. Hubungan yang terjalin antara atasan dan bawahan pada saat menjalankan berbagai tugas melibatkan proses pengendalian didalamnya. Proses pengendalian manajemen memiliki empat aktivitas yaitu: (Anthony \& Govindarajan, 2009): Perencanaan Strategis, Persiapan Anggaran, Pelaksanaan, Evaluasi Kerja.

Sutabri, (2014) menyatakan teknologi informasi adalah suatu pemanfaatan teknologi seperti komputer yang digunakan untuk mengolah,memproses, mendapatkan, menyusun, menyimpan, memanipulasi data yang menghasilkan informasi yang berkualitas. Informasi yang berkualitas adalah informasi yang akurat, relevan dan tepat waktu yang kemudian dimanfaatkan oleh pengguna informasi sesuai dengan kepentingan mereka. Sedangkan Maharsi (2000) mengemukakan bahwa teknologi informasi merupakan penggabungan dari telekomunikasi, teknologi komputer, dan teknologi pendukung lainnya seperti hardware, software, database, jaringan dan perangkat telekomunikasi yang lain. Dalam sistem informasi, teknologi informasi bertugas menyediakan informasi bagi para pemakainya dimana dalam hal ini seorang manajer sebagai pemakai informasi yang digunakan dalam proses pengambilan keputusan. Informasi yang didapatkan diharapkan dapat membantu manajer dalam mengidentifikasi dan mengevaluasi dari permasalahan yang dihadapi hingga mendapatkan jalan keluarnya, sehingga informasi yang didapat haruslah informasi yang berkualitas.

Teknologi informasi memungkinkan sejumlah besar informasi yang berguna dapat dikumpulkan dan dilaporkan kepada manajer dengan segera. Apa yang terjadi diberbagai bagian dapat diketahui dalam sekejap. Ini memungkinkan manajemen dapat mengambil keputusan secara lebih cepat. Teknologi informasi akan memungkinkan untuk mewujudkan fungsi kontrol manajemen secara lebih efektif. Di sisi lain, kontrol manajemen akan memungkinkan untuk meningkatkan kualitas arus informasi, meningkatkan kecepatan, keandalan, dan keakuratannya (Vasilev \& Akhmetshin, 2014). Teknologi informasi dapat membantu perusahaan dalam memperoleh informasi yang kompetitif. Dengan adanya pemrosesan dengan menggunakan teknologi komputer, maka akan ada jejak-jejak transaksi (transaction trails). Beberapa sistem komputer dirancang agar jejak transaksi lengkap yang berguna untuk tujuan pemeriksaan dapat tersedia dalam jangka waktu singkat atau hanya dalam bentuk yang dapat dibaca oleh komputer. kemudian pemrosesan transaksi dilakukan secara seragam (uniform processing of transaction).

Model hubungan sistem informasi akuntasi manajemen, sistem pengendalian 
manjemen, teknologi informasi dan kinerja manjerial digambarkan sebagai berikut:

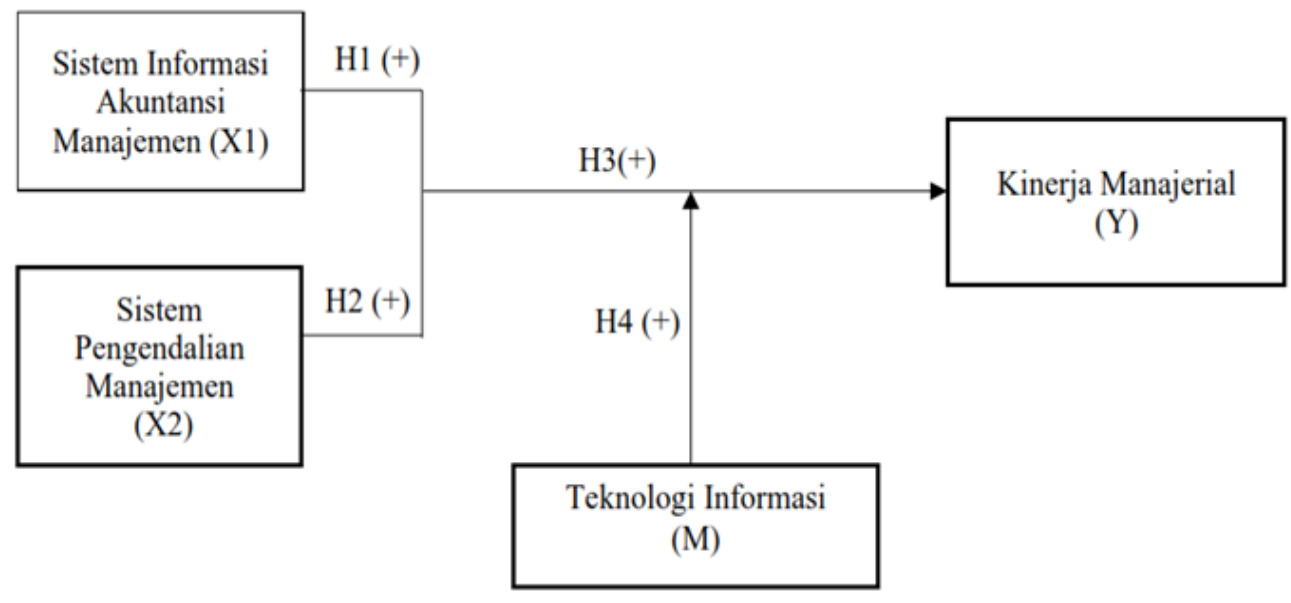

Gambar 1. Model Interaksi Sistem Informasi Akuntansi Manajemen, Sistem Pengendalian Manajemen Dengan Teknologi Informasi Terhadap Kinerja Manajerial

\section{METODE}

Populasi yang digunakan adalah manajer / pimpinan / kepala bagian dengan memiliki pengalaman kerja minimal 1 tahun pada perusahaan mereka bekerja, mengetahui mengenai strategi, teknologi dan sistem cara kerja didalam perusahaan Garmen yang sudah berbentuk Perseroan Terbatas (PT) dan terdaftar pada data Badan Pusat Statistik (BPS) di Kota Semarang yang berjumlah 200 manajer. Pengambilan sampel menggunakan teknik probability sampling. (Sugiyono, 2017) Penentuan sampel dengan nggunakan rumus slovin diperoleh jumlah sampel 67.

Variabel terikat (dependent): Kinerja manajerial (Y) dengan indikator penelitian Perencanaan, Investigasi, Koordinasi, Supervisi, Staffing, Negosiasi, Representasi, Evaluasi (Missah et al., 2019). Variabel bebas (independent) : Sistem informasi akuntansi manajemen (X1) dengan indikator penelitian Broadscope, Timeliness, Aggregation, Integration (Rumapea et al., 2018), Sistem pengendalian manajemen (X2) dengan indikator penelitian Perencanaan strategis, Persiapan anggaran, Pelaksanaan, Evaluasi kinerja (Tendean et al., 2018). Variabel moderating Teknologi informasi (M) dengan indikator penelitian Menangkap informasi, Menyampaikan informasi, Menciptakan informasi, Menyimpan informasi, Mengkomunikasikan informasi (Alliyah, 2015). Data primer digunakan untuk penelitian ini, diperoleh melalui kuisioner. dengan menggunakan 5 skala Likert.

Uji validitas dilakukan dengan membandingkan nilai $r$ hitung dengan $r$ tabel untuk tingkat signifikansi $5 \%$. Hasil uji validitas menunjukan $r$ hitung 0,274 (paling rendah) dan 0,784 (tertinggi) lebih besar dari $r$ tabel $(0,244)$ artinya semua pertanyaan/pernyataan kuesioner valid dan dapat digunakan untuk penelitian.

Hasil uji reliabilitas menunjukan indikator variabel Kinerja Manajerial nilai cronbach alpha 0,828, Sistem Informasi Akuntansi Manajemen nilai cronbach alpha 0,794, Sistem Pengendalian Manajemen nilai cronbach alpha 0,721 dan Teknologi Informasi memiliki nilai cronbach alpha 0,641 diatas nilai batas 0,60 artinya kuesioner yang digunakan untuk mengukur variabel handal/reliabel.

Analisis statistik yang digunakan untuk menguji hipotesis pertama dan kedua adalah analisis regresi berganda sebagai model memprediksi dan mempelajari hubungan kausal antara variabel dependen dan beberapa variabel independen. Untuk menguji hubungan sistem informasi akuntansi manajemen, sistem pengendalian 
manajemen terhadap kinerja manajerial.

$$
\mathrm{Y}=\mathrm{a}+\beta 1 \mathrm{X} 1+\beta 2 \mathrm{X} 2+\mathrm{e}
$$

(Ghozali, 2018)

Keterangan :

$\mathrm{Y}=$ Kinerja manajerial

$\mathrm{B} 1, \beta 2,=$ koefisien regresi

$\mathrm{a}=$ konstanta

$\mathrm{e}=$ error

$\mathrm{X} 1$ = Sistem Informasi Akuntansi Manajemen

X 2 = Sistem Pengendalian Manajemen

Analisis yang digunakan untuk uji variabel moderating hipotesis 3 dan hipotesis 4 dilakukan dengan menggunakan analisis regresi metode interaksi dimana dalam persamaan regresi mengandung unsur interaksi atau perkalian antara variabel independen dengan variabel moderating.

Berikut Meregresikan variabel $\mathrm{X}, \mathrm{M}$ dan Interaksi $\mathrm{X}$ dan $\mathrm{M}$ terhadap $\mathrm{Y}$ :

$Y=a+\beta 1 . X 1+\beta 2 . . x 2+\beta 3 . X 1 . M+\beta 4 . X 2 . M+e$

(Ghozali, 2018)

\section{Keterangan :}

$\mathrm{B} 3, \beta 4=$ koefisien variabel moderasi

MX1 = interaksi M dan X1

MX2 = interaksi M dan X2

\section{HASIL}

Manajer perusahaan garmen di Semarang sebagian besar perempuan sebanyak 52 orang $(77,6 \%)$ sedangkan yang laki-laki sebanyak 15 orang $(22,4 \%)$. Manajer perusahaan garmen sebagian besar adalah berjenis kelamin perempuan karena industri garmen membutuhkan ketelitian dan kerapian yang sangat identik dengan perempuan, sehingga mereka lebih banyak menyerap tenaga kerja wanita. Hal tersebut mendukung terbentuknya manajer yang berasal dari yang sudah lama bekerja yang mempunyai loyalitas dan kredibilitas kepada perusahaan.

Manajer perusahaan garmen di Kota Semarang sebagian besar mempunyai pendidikan D3 sebanyak 21 orang $(31,3 \%)$, sedangkan yang mempunyai pendidikan S1 sebanyak 46 orang $(68,7 \%)$. Manajer pasusahaan garmen yang ada di Kota Semarang mempunyai pendidikan yang baik yaitu sarjana muda dan sarjana. Pendidikan mereka yang baik tersebut sangat mendukung dalam pengelolaan perusahaan dimana mereka bisa menjalankan fungsi sebagai manajer.

Manajer perusahaan garmen di Semarang sebagian besar mempunyai masa kerja 110 tahun yaitu sebanyak 50 orang (74,6\%) sedangkan yang mempunyai masa kerja 11-20 tahun sebanyak 17 orang $(25,4 \%)$. Manajer perusahaan garmen yang ada di Kota Semarang mempunyai masa kerja yang cukup lama yaitu berkisar dari 10 tahun. Lama kerja yang cukup lama tersebut membentuk pengalaman dalam bekerja yang sangat mendukung dalam pengelolaan perusahaan.

Manajer perusahaan garmen di Kota Semarang yang berusia 21-30 tahun sebanyak 12 orang (17.9\%), yang berusia 31-40 tahun sebanyak 29 orang (43,3\%), yang berusia 41-50 tahun sebanyak 19 orang $(28,4 \%)$, sedangkan yang berusia lebih dari 50 tahun sebanyak 7 orang $(10,4 \%)$. Hal tersebut menunjukkan bahwa sebagian besar manajer perusahaan garmen di Kota Semarang mempunyai usia lebih dari 31-40 tahun. Semakin bertambah usia seseorang manajer maka semakin berkembang daya tangkap, pola pikir dan memiliki lebih banyak pengalaman sehingga lebih bijaksana dalam mengambil 
keputusan.

Responden sebagian besar memiliki jabatan sebagai manajer bagian produksi sebanyak 16 orang atau $(23,9 \%)$, jabatan sebagai manajer operasional sebanyak 14 orang atau $(20,9 \%)$, manajer pemasaran sebanyak 11 orang atau $(16,4 \%)$, serta manajer HR dan manajer keuangan sebanyak 13 orang atau $(19,4 \%)$.

Uji normalitas dilakukan dengan mengunakan Kolmogorov-smirnov dengan kriteria penerimaan normalitas adalah jika nilai signifikansi Kolmogorov-smirnov lebih besar dari 0,05 . Berdasarkan hasil penelitian diketahui bahwa tingkat signifikansi variable penelitian persamaan 1 adalah $0,732>0,05$ dan persamaan 2 adalah $0,134>0,05$ maka model regresi terdistribusi normal, oleh sebab itu dapat dilakukan proses selanjutnya.

Hasil uji multikolinieritas menunjukkan hasil nilai tolerance untuk semua variabel sistem informasi akuntansi manajemen $(0,950)$, sistem pengendalian manajemen $(0,795)$, teknologi informasi $(0,768)$ lebih dari 0,10 dan nilai VIF kurang dari 10. Hal ini menunjukkan bahwa variabel independen bebas multikolinearitas.

Hasil Uji heterokedastisitas dengan menggunakan metode uji Glejser. persamaan 1 sistem : informasi akuntansi manajemen nilai sig 0,430 , sistem pengendalian manajemen nilai sig 0,230 lebih dari 0,05. Persamaan 2: interaksi SIAM dengan TI nilai probabilitas 0,353 dan interaksi SPM dengan TI nilai probabilitas 0,295 dapat diketahui bahwa nilai signifikansi lebih dari 0,05, sehingga dapat disimpulkan bahwa dalam penelitian ini tidak terjadi heterokedastisitas pada model regresi.

Hasil analisis pengaruh sistem informasi akuntansi manajemen (X1), sistem pengendalian manajemen (X2), dan tekonologi informasi sebagai variable moderating (M) terhadap kinerja manajerial (Y) dapat dinyatakan dalam bentuk persamaan sebagai berikut :

Tabel 1. Hasil regresi persamaan 1

\begin{tabular}{|c|c|c|c|c|c|c|}
\hline & \multicolumn{2}{|c|}{$\begin{array}{l}\text { Unstandardized } \\
\text { Coefficients }\end{array}$} & $\begin{array}{l}\text { Standardized } \\
\text { Coefficients }\end{array}$ & \multirow[b]{2}{*}{ ig } & \multicolumn{2}{|l|}{$\begin{array}{l}\text { Collinearity } \\
\text { Statistics }\end{array}$} \\
\hline & $\bar{B}$ & Std. Error & Beta & & Tolerance & VIF \\
\hline (Constant) & 11.370 & 7.907 & & 1.4 .155 & & \\
\hline SIAM & .330 & .051 & .626 & 6.4 .000 & .955 & 1.048 \\
\hline SPM & .398 & .191 & .221 & 2.0 .042 & .795 & 1.258 \\
\hline
\end{tabular}

a. Dependent Variable: kinerja_manajerial

Sumber : Data primer yang diolah 2020

$$
\mathrm{Y}=11,370+0,330 \mathrm{X} 1+0,398 \mathrm{X} 2+\mathrm{e}
$$

Berdasarkan persamaan regresi berganda pertama dapat dijelaskan sebagai berikut: $\mathrm{a}=$ 11,370 positif, artinya apabila SIAM, SPM dan teknologi informasi konstan maka kinerja manajerial meningkat. b1 bernilai 0,330, artinya sistem informasi akuntansi manajemen mempunyai hubungan positif terhadap kinerja manajerial. Jika sistem informasi akuntansi manajemen ditingkatkan maka kinerja manajerial akan meningkat, dengan asumsi sistem pengendalian manajemen dan teknologi informasi tetap. b2 bernilai 0,398 (positif), artinya sistem pengendalian manajemen mempunyai hubungan positif terhadap kinerja manajerial. Jika sistem pengendalian ditingkatkan maka kinerja manajerial juga akan meningkat, dengan asumsi sistem informasi akuntansi manajemen dan teknologi informasi tetap. 
Tabel 2. Hasil Regresi Persamaan 2

\begin{tabular}{llllll}
\hline & \multicolumn{2}{l}{$\begin{array}{l}\text { Unstandardized } \\
\text { Coefficients }\end{array}$} & \multicolumn{2}{l}{$\begin{array}{l}\text { Standardized } \\
\text { Coefficients }\end{array}$} & \\
\cline { 2 - 4 } Model & \multicolumn{1}{c}{$\mathrm{B}$} & \multicolumn{1}{c}{ Std. Error } & \multicolumn{1}{c}{ Beta } & & Sig. \\
\hline (Constant) & 574.475 & 51.434 & & 11.169 & .000 \\
SIAM & 5.055 & 1.728 & 9.594 & 2.925 & .005 \\
SPM & 18.973 & 2.129 & 10.541 & 8.912 & .000 \\
MOD1 & .231 & .087 & 8.434 & 2.652 & .010 \\
MOD2 & 1.018 & .115 & 19.219 & 8.879 & .000 \\
\hline
\end{tabular}

Dependent Variable: kinerja_manajerial

Sumber : Data primer yang diolah 2020

$$
\begin{aligned}
& \mathrm{Y}=\mathrm{a}+\beta 1 \cdot \mathrm{X} 1+\beta 2 \cdot \mathrm{X} 2+\beta 3 \cdot \mathrm{X} 1 \cdot \mathrm{M}+\beta 4 \cdot \mathrm{X} 2 \cdot \mathrm{M}+\mathrm{e} \\
& \mathrm{Y}=574,475+5,055 \mathrm{X} 1+18,973 \mathrm{X} 2+0.231 \mathrm{X} 1 \cdot \mathrm{M}+1 \cdot 018 \mathrm{X} 2 .
\end{aligned}
$$

Hasil persamaan regresi ke 2 tersebut di atas memberikan pengertian bahwa Nilai konstanta, bernilai 575,475 positif dapat diartikan bahwa apabila sistem informasi akuntansi manajemen, sistem pengendalian manajemen konstan atau tetap, maka kinerja manajerial bernilai positif. Nilai koefisien regresi sistem informasi akuntansi manajemen 5,055 positif mempunyai arti bahwa apabila sistem informasi akuntansi manajemen semakin baik, maka kinerja manajerial akan semakin baik pula. Nilai koefisien regresi sistem Pengendalian manajemen sebesar 18, 97 positif, mempunyai arti bahwa apabila sistem pengendalian manajemen semakin baik, maka kinerja manajerial akan semakin baik. Koefisien regresi moderating sistem informasi akuntansi manajemen terhadap kinerja manajerial yang dimoderasi oleh teknologi informasi bernilai 0,231 , bernilai positif, mempunyai arti bahwa apabila teknologi informasi dapat memperkuat pengaruh antara sistem informasi akuntansi manajemen terhadap kinerja manajerial. Koefisien regresi moderating sistem pengendalian manajemen terhadap kinerja manajerial yang dimoderasi oleh teknologi informasi 1,018 bernilai positif mempunyai arti bahwa apabila teknologi informasi dapat memperkuat pengaruh antara sistem pengendalian manajemen terhadap kinerja manajerial.

Tabel 3 . Koefisien determinasi

\section{Model Summaryb Goodness of Fit Koefisien Determinasi $\left(\mathbf{R}^{2}\right)$}

\begin{tabular}{cccc}
\hline Model & R & R Square & $\begin{array}{c}\text { Adjusted } \\
\text { R Square }\end{array}$ \\
\hline $\mathbf{1}$ & $\mathbf{. 9 0 0 a}$ & $\mathbf{. 8 1 0}$ & $\mathbf{. 7 9 5}$ \\
\hline
\end{tabular}

Sumber : data primer yang diolah 2020

Determinasi yang dihasilkan oleh model regresi ditunjukkan oleh $R$ Square pada analisis regresi. Dari tabel 3 Dapat disimpulkan bahwa kinerja manajerial dipengaruhi oleh Sistem Informasi Akuntansi Manajemen, Sistem Pengendalian Manajemen dan teknologi informasi sebesar 79,5\%, sedangkan sisanya sebesar 20,5\% dijelaskan oleh faktor-faktor lain yang tidak dimasukkan ke dalam penelitian ini

Berdasarkan hasil uji statistik t pada tabel 1 dapat disimpulkan bahwa :

Variabel sistem informasi akuntansi memiliki nilai sig. sebesar 0,000 lebih kecil dari 0,05 sehingga Hipotesis 1 : sistem informasi akuntansi berpengaruh positif signifikan terhadap 
kinerja manajerial perusahaan garmen di kota semarang diterima. Variabel sistem pengendalian manjemen memiliki nilai sig. 0,042 lebih kecil dari 0,05 sehingga Hipotesis 2: Sistem pengendalian manjemen berpengaruh positif signifikan terhadap kinerja manajerial perusahaan garmen di kota semarang diterima.

Hasil uji Statistik pada table 2 menunjukan Variabel sistem informasi akuntansi manajemen terhadap kinerja manajerial yang dimoderasi dengan teknologi informasi memiliki nilai sig. 0,01 lebih kecil dari 0,05 sehingga Hipotesis 3 diterima, artinya interaksi sistem akuntansi manajemen dengan teknologi informasi berpengaruh positif signifikan terhadap kinerja manajerial perusahaan garmen di kota semarang. Variabel sistem pengendalian manajemen terhadap kinerja manajerial yang dimoderasi dengan teknologi informasi memiliki nilai sig. 0,00 lebih kecil dari 0,05 sehingga Hipotesis 4 diterima. Artinya interaksi sistem pengendalian manajemen dengan teknologi informasi berpengaruh positif signifikan terhadap kinerja manajerial perusahaan garmen di kota semarang.

\section{PEMBAHASAN}

Sistem informasi akuntansi manajemen yang tersedia akan menjadi efektif apabila sesuai dengan tingkat kebutuhan organisasi. Sistem informasi akuntansi manajemen telah teridentifikasi sangat penting dalam membantu pengambilan keputusan manajerial sehingga sistem informasi akuntansi yag semakin baik akan meningkatkan kinerja majaerial. Semakin tersedianya sistem informasi akuntansi manajemen dengan karakteristik broadscope, timeliness, agregation dan integration maka akan semakin membantu dalam meningkatkannya kinerja manajerial. Hasil penelitian ini sejalan dengan Penelitian (Febrianti \& Fitri, 2019) dan Rumapea et al., (2018) mengungkapkan sistem informasi akuntansi manajemen berpengaruh positif signifikan terhadap kinerja manajerial, sedikit berbeda dengan hasil penelitian Missah et al., (2019) yang menunjukan integrasi tidak berpengaruh terhadap kinerja manajerial.

Sistem Pengendalian manajemen berpengaruh positif signifikan terhadap kinerja manajerial. Semakin baik pelaksanaan sistem pengendalian manajemen maka semakin baik pula kinerja manajerial. Sistem pengendalian manajemen merupakan sistem yang mempunyai fungsi sebagai suatu wadah untuk merencanakan target yang akan dicapai perusahaan dimasa mendatang. Menyusun aktivitas-aktivitas, mempraktekan serta mengawasi aktivitas dari pelaksanaan yang sudah direncanakan agar tetap pada jalurnya. Hal ini sejalan dengan tujuan dari pengendalian manajemen yakni untuk memperoleh informasi yang terintegrasi dan andal, Mengukur ketaatan pada prosedur dan peraturan yang sudah ditetapkan Apabila manajemen telah mampu melakukan ini dengan baik maka dengan sendirinya akan memberikan jaminan kepada manajemen untuk mencapai tujuan dan sasaran organisasinya. Apabila tujuan dan sasaran organisasi telah dicapai maka dengan demikian akan meningkatkan kinerja manajer itu sendiri. Penelitian Tendean et al., (2018), (Sugianto Yusuf et al., 2018) dan Rahmad et al., (2016) menghasilkan temuan bahwa Sistem pengendalian manajemen mempunyai pengaruh positif signifikan terhadap kinerja manajerial.

Interaksi sistem informasi akuntansi manajemen dengan teknologi informasi memperoleh hasil positif signifikan terhadap kinerja manajerial. Teknologi informasi dapat membantu perusahaan dalam memperoleh informasi yang kompetitif. Dengan adanya pemrosesan menggunakan teknologi komputer, maka akan ada jejak-jejak transaksi (transaction trails). Beberapa sistem komputer dirancang agar jejak transaksi lengkap yang berguna untuk tujuan pemeriksaan dapat tersedia dalam jangka waktu singkat atau hanya dalam bentuk yang dapat dibaca oleh komputer. Teknologi informasi mengintegrasikan data dari berbagai bagian, dan mempercepat penyajian data yang dibutuhkan untuk 
pengambilan keputusan sehingga kinerja manajerial akan semakin baik Penelitian Rahmanuari (2017) menemukan bahwa interaksi karakteristik sistem informasi akuntansi manajemen dengan teknologi informasi memperoleh hasil positif signifikan. Artinya interaksi antara teknologi informasi dan karakteristik sistem informasi akuntansi manajemen memperkuat pengaruh karakteristik sistem informasi akuntansi manajemen terhadap kinerja manajerial. Penelitian Gurendrawati \& Murdayanti, (2015) menyimpulkan Teknologi Informasi, Karakteristik Sistem Akuntansi Manajemen, berpengaruh positif signifikan terhadap Kinerja Manajerial. Teknologi Informasi dan Karakteristik Sistem Akuntansi Manajemen sangat membantu semua pengelola tugas terutama dalam pengambilan keputusan yang diperlukan mengenai pertimbangan perusahaan serta informasi dan pembaruan yang berguna.

Pengaruh Interaksi sistem pengendalian manajemen dengan teknologi informasi memperoleh hasil positif signifikan. Teknologi informasi memperkuat pengaruh sistem pengendalian manajemen terhadap kinerja manajerial perusahaan garmen Kota Semarang. Teknologi informasi memungkinkan sejumlah besar informasi yang berguna dapat dikumpulkan dan dilaporkan kepada manajer dengan segera, sehingga yang terjadi diberbagai bagian operasional dan produksi dapat diketahui dengan segera. Kehadiran teknologi informasi memberikan banyak manfaat bagi perusahaan, mampu meringankan aktivitas bisnis yang kompleks seperti perencanaan strategis, persiapan anggaran , pelaksanaan anggaran dan mengevaluasi kinerja serta menghasilkan informasi yang dapat dipercaya, relevan, tepat waktu, lengkap, dapat dipahami, dan teruji dalam rangka perencanaan, pengendalian dan pengambilan keputusan manajemen. Selain itu efisiensi operasi perusahaan dan kinerja perusahaan juga dapat ditingkatkan. Akibatnya perusahaan dapat tetap bertahan dalam era informasi serta mampu menghadapi persaingan pasar global. Ini memungkinkan manajemen dapat mengambil keputusan secara lebih tepat dan cepat. Hasil penelitian ini mendukung penelitian Rahmanuari, (2017) yang menemukan bahwa interaksi sistem pengendalian manajemen dengan teknologi informasi memperoleh hasil positif signifikan. Artinya interaksi antara sistem pengendalian manajemen dan teknologi informasi dapat memperkuat pengaruh sistem pengendalian manajemen terhadap kinerja manajerial. Dan sejalur dengan hasi penelitian Handayani et al., (2020) yang menyatakan ada pengaruh yang positif dan signifikan antara sistem pengendalian intern pemerintah, pemanfaatan teknologi informasi dan komitmen organisasi terhadap akuntabilitas kinerja instansi pemerintah.

\section{KESIMPULAN}

Berdasarkan uji hiptesis dan pembahasan maka dapat disimpulkan: Sistem informasi akuntansi manajemen berpengaruh positif signifikan terhadap kinerja manajerial perusahaan garmen kota Semarang, apabila sistem informasi akuntansi manajemen semakin baik maka kinerja manajerial semakin baik. Sistem pengendalian manajemen berpengaruh positif signifikan terhadap kinerja manajerial perusahaan garmen kota Semarang, apabila sistem pengendalian manajemen meningkat maka kinerja manajerial semakin baik. Interaksi sistem informasi akuntansi manajemen dengan teknologi informasi mempunyai hasil positif signifikan terhadap kinerja manajerial, artinya teknologi informasi memperkuat pengaruh sistem informasi akuntansi terhadap kinerja manajerial perusahaan garmen kota Semarang. Interaksi sistem pengendalian manajemen dan teknologi informasi mempunyai hasil positif signifikan, artinya teknologi informasi memperkuat pengaruh sistem pengendalian manajemen terhadap kinerja manajerial perusahaan garmen Semarang. 


\section{REFERENSI}

Alliyah, S. (2015). Pengaruh Penggunaan, Teknologi Informasi Terhadap Kualitas Keputusan melalui karakteristik sistem akuntansi manajemen Dengan Saling Ketergantungan Sebagai Variabel Moderating. Buletin Bisnis \& Manajemen, 01(01), 54-72.

Anthony, N., \& Govindarajan, V. (2009). Sistem pengendalian manajemen buku 1. Salemba Empat.

Febrianti, R., \& Fitri, Y. (2019). Pengaruh Karakteristik Informasi Sistem Akuntansi Manajemen, Ketidakpastian Lingkungan, Dan Desentralisasi Terhadap Kinerja Manajerial (Studi Empiris Pada Perusahaan Bumn Di Banda Aceh). Jurnal Ilmiah Mahasiswa Ekonomi Akuntansi, 4(3), 257-269. https://doi.org/10.24815/jimeka.v5i2.15561

Fuadah, L. L., Safitri, R. H., Yulianil, Y., \& Arisman, A. (2020). Determinant Factors' Impact on Managerial Performance through Management Accounting Systems in Indonesia. Journal of Asian Finance, Economics and Business, 7(10), 109-117. https://doi.org/10.13106/jafeb.2020.vol7.no10.109

Ghozali, I. (2018). Aplikasi Analisis Multivariate dengan Program IBM SPSS 25. UNDIP Semarang.

Gurendrawati, E., \& Murdayanti, Y. (2015). The Impact Of Information Technology, Management Accounting System Characteristics, and Locus Of Control To The Managerial Performance In The Telecommunication Service Companies. Review of Integrative Business \& Economics, 4(1), 357-366. http://search.proquest.com/openview/01bba4f54440c69e9c74bb33effca4d2/1?pqorigsite $=$ gscholar

Handayani, D., Afiah, N. N., \& Yudianto, I. (2020). The Influence of Internal Control System , Information Technology Utilization, and Organizational Commitment on Government Accountability Performance. Journal of Accounting Auditing and Business, 3(2), 17-29. https://doi.org/DOI: https://doi.org/10.24198/jaab

Irawati, A., \& Ardianshah, R. (2018). Pengaruh Karakteristik Sistem Iinformasi Akuntansi Manajemen Terhadap Kinerja Manajerial Dengan Desentralisasi Sebagai Variabel Moderating. JURNAL Akuntansi \& Keuangan, 1(9), 34 - 53.

Missah, L. N., Ilat, V., \& Tirayoh, V. Z. (2019). Pengaruh karakteristik informasi akuntansi manajemen terhadap kinerja manajerial pada PT. Bank Sulutgo. Indonesia Accounting Journal, 1(2), 39. https://doi.org/10.32400/iaj.26176

Nainggolan, E. P. (2015). Pengaruh Karakteristik Sistem Informasi Akuntansi Manajemen Terhadap Kinerja Organisasi Dengan Tingkat Desentralisasi Sebagai Variabel Moderating. Jurnal Riset Akuntansi Dan Bisnis, 15(1), 100-112. https://doi.org/10.30596/jrab.v15i1.430

Rahmad, R., Lestari, R., \& Fitriah, E. (2016). Pengaruh Penerapan Sistem Pengendalian Manajemen Terhadap Kinerja Manajerial. Prosiding Akuntansi, 2(2), 467-472.

Rahmanuari, C. (2017). Analisis Pengaruh Pengrndalian Internal Dan Karakteristik Sistem Informasi Akuntansi Manajemen Terhadap Kinerja Manajerial Dengan Teknologi Informasi Sebagai Variabel moderating Pada Perbankan Syariah Di Pekanbaru). Skripsi thesis, Universi [Universitas Islam Negeri Sultan Syarif Kasim Riau]. In

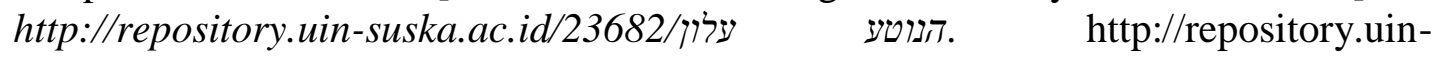
suska.ac.id/23682/

Rumapea, M., Sinaga, J., \& Saragih, R. E. (2018). Pengaruh Penerapan Sistem Informasi Akuntansi Manajemen, Metode Pengukuran Kinerja Dan Sistem Penghargaan Terhadap Kinerja Manajerial Pada Rumah Sakit ESTOMIHI Medan. Jurnal 
Manajemen Informatika \& Komputerisasi Akuntansi, 2(1), 63-73.

Sugianto Yusuf, P., Haizam Mohd Saudi, M., Nurmalasari, T., \& Surayya Mohd Saudi, N. (2018). The Effect of Management Control System and Leadership Style on Managerial Performance (An Empirical Studies on SOE Company in Bandung). International Journal of Engineering \& Technology, 7(4.34), 274. https://doi.org/10.14419/ijet.v7i4.34.25292

Sugiyono. (2017). Metode Penelitian: Kuantitatif Kualitatif dan $R \&$ D. ALFABETA.

Sumarsan, T. (2013). Sistem Pengendalian Manajemen: Konsep, Aplikasi, dan Pengukuran Kinerja. PT. Indeks. Jakarta Barat.

Sutabri, T. (2014). Pengantar Teknologi Informasi. Andi, Yogyakarta.

Tendean, A. B., Saerang, D. P. E., \& Runtu, T. (2018). Pengaruh Struktur Sistem Pengendalian Manajemen, Proses Sistem Pengendalian Manajemen Dan Sistem Penghargaan Terhadap Kinerja Manajerial (Studi Pada Rsud Sulawesi Utara). Going Concern: Jurnal Riset Akuntansi, 13(04), 597-610. https://doi.org/10.32400/gc.13.03.20776.2018

Vasilev, V. L., \& Akhmetshin, E. M. (2014). The role of information and information technology in the management control function. Biosciences Biotechnology Research Asia, 11(3), 1469-1474. https://doi.org/10.13005/bbra/1540 